\title{
Youth Transitions and Interdependent Adult-child Relations in Rural Bolivia
}

\author{
Samantha Punch \\ Department of Applied Social Science \\ University of Stirling \\ Stirling \\ FK9 4LA \\ Scotland
}

\begin{abstract}
There are few studies which document youth transitions from school to work in rural areas of the majority world. This paper, based on ethnographic fieldwork in a rural community in Bolivia, considers how young people make decisions about different types of school-to-work transitions which include migrating to continue their formal education, working in the community, or seeking migrant work in the regional town or in neighbouring Argentina. The paper explores how young people negotiate structural constraints over their choice of transition, including the rural location, economic resources, parental attitudes and family background, gender, birth order, social networks and role models. Importantly the paper highlights that underlying young people's choice of transition are interdependent household relations. In the majority world, in this case in Bolivia, rural young people may achieve economic independence sooner than those in the minority world, but long-term family interdependence tends to be maintained throughout the life-course. This paper suggests that the notion of negotiated interdependence is a more appropriate way to understand youth transitions and relations between young people and adults in rural areas of the majority world.
\end{abstract}

Key words

Bolivia, Children, Interdependence, Transitions, Young People 


\section{Youth Transitions and Interdependent Adult-child Relations in Rural Bolivia}

Most research about youth transitions, including comparative studies, are concentrated not only in urban areas but also are mainly based in the minority world ${ }^{1}$ (for example Bynner, 2001; Du Bois-Reymond, 1998; MacDonald, 1998; Rudd and Evans, 1998). The aim of this paper is to to explore school-to-work youth transitions in rural Bolivia, a poor area of the majority world where young people are particularly constrained by poverty and the relative isolation of their rural location. Yet, despite such limited work and education opportunities, young people still manage work to within these constraints and assert some agency over their lives.

The article begins by discussing the existing debate on youth transitions before outlining the background to the study and the potential transitions that are available to young people in rural Bolivia. The structural influences which constrain their choice of transition are examined including the rural location, economic resources, parental attitudes and family background, gender, birth order, social networks and role models. The paper highlights how the notion of negotiated interdependence is a useful way of understanding how young people work within their structural limitations whilst fulfilling both individual and household needs and asserting some level of agency over their choice of transition.

\section{Recent debates regarding youth transitions}

Childhood and youth research widely recognises that it is inadequate to consider the transition from childhood to youth to adulthood in terms of a linear progression from 
dependence to independence (Du Bois-Reymond, 1998; Furlong and Cartmel, 1997; Rudd and Evans, 1998; Wyn and Dwyer, 1999). In the minority world, due to changes in family structures, education and the labour market, youth transitions have become longer, interrupted and more complex (Chisholm and Du Bois-Reymond, 1993; EGRIS, 2001; Furlong and Cartmel, 1997; Wyn and Dwyer, 1999). This has led to more options for young people but has also created much uncertainty (Chisholm and Du Bois-Reymond, 1993; Furlong and Cartmel, 1997) and increased financial dependency on their parents (Raffo and Reeves, 2000; Schneider, 2000). In the minority world young people are now more likely to undergo a series of transitions, moving in and out of independence and dependence in different contexts and in relation to different people (EGRIS, 2001), yet still the ultimate goal is to achieve independence (Gillies, 2000).

However, this paper will argue that young people in rural Bolivia are more likely to experience interdependent social relations. The notion of interdependence could be a useful way of understanding how young people move in and out of relative autonomy and dependence. It has been argued that in poor areas of the majority world, parentchild relations are more interdependent than in much of the minority world mainly because children work from a young age and can be active contributors to the maintenance of their household (Boyden et al. 1998). Elsewhere I have shown that household divisions of labour in rural Bolivia are based on interdependent relations between parents and their children and between siblings (Punch, 2001c) and that these are negotiated and renegotiated over time and space (Punch, 2001a). In this paper, I aim to show that youth transitions are also influenced by interdependent household 
relations which are not fixed but are worked out and renegotiated according to different constraints and opportunities which exist.

Therefore, in a majority world context, the notion of 'youth transition' from dependent child to independent adult is problematic since young people negotiate and renegotiate their interdependence with their parents and siblings throughout the lifecourse. At this point it is worth highlighting that we also have to be careful how we use the term ‘youth' since it is a minority world concept that cannot be used unproblematically in the majority world. Whilst recognising that further research into the usefulness of the term in different cultural contexts would be appropriate, for the purposes of this paper 'youth' is used as:

... a relational concept, which refers to the social processes whereby age is socially constructed, institutionalised and controlled in historically and culturally specific ways. (Wyn and White, 1997: 10-11)

Recently the use of the concept of 'transition' has also been questioned in minority world contexts (Cohen and Ainley, 2000; EGRIS, 2000; Wyn and Dwyer, 1999) and Gillies (2000) argues that there are three main drawbacks of using the term. First, it does not allow for greater recognition of the blurred boundaries between dependence and independence. Secondly it tends to imply an individualistic transition whilst placing less emphasis on family interrelationships and thirdly youth becomes conceptualised merely as a transitional period of change and instability rather than being a special category in its own right (Gillies, 2000). 
However, despite these drawbacks, it is recognised that the concept of 'transition' can still provide a useful framework for exploring the ways in which young people are constrained and their decision-making processes in relation to their chosen school-towork pathways (Bynner, 2001; Gillies, 2000). Thus this paper uses transition as a starting point for examining how young people in an impoverished rural area of the majority world understand their choices regarding when to leave school and what work to seek. Apart from the school-to-work trajectories, youth transitions also include leaving home, starting a sexual relationship, having children and acquiring citizenship rights (EGRIS, 2001). It is widely recognised that these transitions are interlinked and that it is important to take a holistic perspective in order to understand the interconnections between them (MacDonald, 1998; Wyn and Dwyer, 1999). Whilst this paper does not have the scope to explore in detail the other youth transitions and will focus mainly on the school-to-work transition, it acknowledges that such transitions are embedded in wider social contexts and can only be fully understood within the interconnecting arenas of their lives.

Another recently recognised aspect of structural accounts of youth transitions, is that they rarely incorporate the voices of the young people concerned (EGRIS, 2001) which has led to calls to integrate structural and cultural approaches to youth studies (Cohen and Ainley, 2000; MacDonald, 1998; Raffo and Reeves, 2000). Thus, one of the aims of this article is to highlight the meanings young people attach to the opportunities and constraints with which they are faced when negotiating their schoolto-work transition. 


\section{Background to the study}

The paper is based on an ethnographic study of rural childhoods in Churquiales, ${ }^{2}$ a community of sixty-eight households in Tarija, southern Bolivia (Punch, 1998). Churquiales is in an economically poor and relatively isolated rural area, lacking basic services such as electricity and drinking water. It is only $55 \mathrm{~km}$ from Tarija, the main regional town, but poor roads, which are sometimes impassable in the rainy season, mean that the twice weekly bus service can take about four hours. The fieldwork included participant observation, classroom task-based methods and interviews with all members of a sample of eighteen households (see Punch, 2001b). The research took place during regular visits between 1993-1995 and a six month intensive period in 1996 and included two visits to north Argentina to interview young migrants who had left the community in search of work.

In Bolivia it is only compulsory for children to attend five years of school and in Churquiales there are six years of primary schooling available but no secondary education. Consequently, young people have to make a decision about their futures once they complete primary school, at 12-13 years of age; somewhat earlier than many of their urban counterparts or than most young people in the minority world whose earliest major transition decision tends to be at 16 years of age (Morrow and Richards, 1996). A decision to continue with secondary school education involves leaving home at a relatively early age and going to live in the town or another larger rural community. 
In this article, the term 'education' is used in the narrow sense of institutional schooling. 'Work' is defined as “activities that produce goods and services for one's own use or in exchange for pay or support” (Reskin and Padavic, 1994: 1) and includes both paid and unpaid work. A broad definition of work is necessary because young people's work options include working within their community by doing either unpaid work for their household or paid work for other households, or seeking migrant work in the town of Tarija or in neighbouring Argentina. Such work is most likely to involve either agricultural labour or domestic work.

Thus young people's work decisions involve choosing between working for their own families or for others, living at home or away, and working in a rural or urban setting. Yet these different kinds of work often overlap. For example, a young person who chooses to stay within their community may do unpaid work for their household, carrying out both domestic and agricultural labour, and may sometimes engage in paid work for other households depending on available opportunities. Their unpaid household work may entitle them to use some of their parents' land for their own crops which they can sell in a local market. Thus in rural Bolivia there are not clear cut distinctions between paid/unpaid work, or home/workplace.

At the time of this study only two girls and two boys were at secondary school. They were all from some of the wealthiest households in the community who could manage to support their education financially. They represented less than 7\% of the sixty $13-$ 19 year olds from Churquiales in 1996. Over half of the young people (52\%) had migrated in search of paid work either in the nearby town or in rural Argentina and 
$42 \%$ had remained within the community to work at home or for another household (see Table 1).

It is worth noting that several young people had already moved between the different options: one boy had given up secondary education to migrate to Argentina, and others had returned to work at home after short periods of migrant work. The main gender difference is that more girls than boys were likely to seek urban migrant work in Bolivia rather than migrate to rural Argentina (to be discussed in the following section). Most young people who choose to work rather than continue their education, tend to spend one or two years working for their household or within their community before migrating in search of higher wages elsewhere (Punch, 1998). However, this paper will focus mainly on young people’s initial decision to choose work or school once they have completed six years of primary education.

At the time of this research there were 59 children in the community primary school (years 1-6 and one year of preschool), with approximately 8-9 children in each year group. In 1996, five boys and four girls completed primary education in Churquiales. One boy went on to secondary school in a nearby rural village, one girl migrated to work in urban Bolivia and one boy migrated to work in rural Argentina, and the other three boys and three girls remained to work within their community. Therefore, on leaving primary school, most 12-13 year olds start full-time work. On the surface it appears that only the elite children in this rural community go to secondary school, but in reality, the circumstances are more complicated than that and there are other factors, besides economics, that influence the decision of poor children to work instead. 


\section{Negotiating structural constraints}

It is well-known that it is difficult to separate structural constraints and young people’s agency because the two are often intertwined (Raffo and Reeves, 2000; Rudd and Evans, 1998; Wyn and Dwyer, 1999). Similarly, different structural factors often combine together to influence what young people decide to do and it can be difficult to determine which is the most influential factor. This section examines the ways in which young people negotiate with a range of structural constraints which are frequently interlinked: the rural location, lack of education opportunities, economic resources, parental attitudes and family background, gender, birth order, social networks and role models.

Rural location: lack of land and local employment

Most of the households in Churquiales own between one and four hectares of land and a small number of animals. Farming provides most of the household's basic food requirements and small surpluses are sold in local and regional markets to provide a limited cash income. In Churquiales most people face the same broad constraints of relative poverty and geographical isolation. The main disadvantages facing young people are lack of access to available land and limited work and education opportunities.

The amount of paid work available to both young people and adults is minimal. Most of the work is seasonal, occurring mainly during the planting and harvesting seasons, and irregular, because much of the land does not have irrigation. Only the wealthiest 
five households employ day labourers regularly and the only other permanent work is on a landed-estate which employs eight day labourers. Therefore, young people have to compete with adults for scarce jobs particularly during the dry season (May to October). In addition, most young people do not own land, they have not yet inherited anything from their parents and they do not have their own personal capital to buy even the smallest of plots.

The main strategy for young people to cope with the lack of access to land and limited economic opportunities is to migrate in search of work in Tarija town or north Argentina (see also Pérez-Crespo, 1991):

I came to Argentina to work, in Churquiales you can't earn anything, I also came to learn how to work on the plantations. The money is for me and for my family, to help my dad. There's no work in Churquiales, I've worked there lots for my family, but they don't pay me. Though in the future I want to go back there. ${ }^{1}$ (Domingo, 14, Pichanal, Argentina)

The daily wage for agricultural or domestic labour is at least four times lower in Churquiales than in Argentina. As Domingo indicates, since earning capacity is greater in Argentina, migration can be a useful temporary transition which enables young people to work regularly and to have the chance to save for their future and perhaps buy their own land.

1 Yo he venido a trabajar, allá no se gana nada, también he venido para aprender a atender almácigos. La plata es para mí y para la casa, para ayudar a mi papá. No hay trabajo en Churquiales. He trabajado mucho allá para la casa, pero no me pagan. Pero en el futuro quiero volver a Churquiales. (Domingo, 14) 
Young people do not only migrate in search of work but those who wish to continue studying beyond primary level are also forced to migrate for education purposes. A vital factor determining whether secondary education is considered as a viable option or not is adults' and children's perception of the benefits of education compared with other available opportunities. One 11 year old girl gave her view that education: "Is nice, you don't get have to get tired or sweat."2 She felt that it was a better option compared with hard physical labour. Such a view of comparing education with work was not untypical and suggests that young people consider education to be physically easier and more of an urban activity than the more rural activity of agricultural labour. Parents also tended to echo this view but felt that formal education was only really beneficial in terms of increased job prospects if it was long-term, leading to urban employment rather than agricultural or domestic labour:

If they keep going until the end they come out as professionals. If they don't keep going, then they don't. Until 5th grade perhaps they don't gain anything, they just know how to write their name, then they don't let themselves be deceived out of money, then they know. But it doesn't help them get a different job. ${ }^{3}$ (Rosaura, parent)

It is often argued that parents do not value education sufficiently and that they are to blame for keeping their children out of school to work:

\footnotetext{
2 Es lindo, no hay que cansarse ni sudar. (Inés, 11)

${ }^{3}$ Salen profesionales hasta el final. Si no siguen ya no. Hasta 5to capaz que no ayuda nada, apenas sabrán escribir su nombre, ya no hacen engañar la plata, ya conocen. Ya no para otro trabajo. (Rosaura, parent)
} 
Here in the rural area many intelligent children have not fulfilled their potential because of a lack of money and lack of parental guidance. They think that it is better that they help in agriculture rather than study, they see it as difficult. ${ }^{4}$ (Ronaldo, teacher)

Yet where the education system is characterised with problems, resulting in repetition and failure, parental attitudes may be more rational than is often assumed (Boyden et al., 1998: 255). In Churquiales there is a range of constraining factors for primary education including lack of educational resources, low wages for teachers, poor teaching quality and household work demands which all lead to high rates of absenteeism, drop-out, repetition and failure (Punch, 1998). Such factors combine and result in a lack of confidence in the benefits of the formal education system.

Primary schooling is perceived as useful for teaching children basic literacy and numeracy skills but not as a pathway to their economic autonomy or to a better social status. Only if children can continue on to secondary education and complete that cycle can they really expect an alternative future livelihood. Thus, where the quality of education is poor and is perceived as unlikely to lead to improved job prospects, then an understandable strategy for young people to adopt is to leave school once basic literacy has been achieved before the financial costs begin to increase substantially.

\footnotetext{
${ }^{4}$ Aquí en el area rural se ha perdido inteligencias por falta de economia y falta de orientación de los padres. Piensan mejor que me ayuda en agricultura que estudie, difícil lo ven. (Ronaldo, teacher)
} 


\section{Economic resources}

The most common reason given by parents, children and teachers for children not continuing to secondary education was a lack of financial resources:

They don't continue studying because of a lack of economic resources. Boarding schools are cheaper, but with transport, materials, it's always an expense. They must have money to pay their board and room, most likely for those that only have one or two children; the important thing is that they have the money. ${ }^{5}$ (Jaime, teacher)

The costs of schooling are two-fold: the indirect costs of the young person's labour which is lost and the direct material costs of formal education, including transport, uniform and shoes (see also Caldwell et al., 1985). Table 2 outlines an estimate of the cheapest costs of secondary schooling for a pupil at a subsidised boarding school ${ }^{3}$ for a school year from February until November.

An annual expenditure of $£ 180$ works out at approximately Bs.120 (£15) a month per child, which is as much as a third of a month's salary for an agricultural labourer. As well as wages from day labourering, households make a living from agriculture and livestock raising, migrant remittances, small businesses such as shops and other activities. However, most households have several children, five or more being not uncommon. Consequently, the possibility of children attending secondary school depends greatly on the financial resources of the household and is by no means an option for all households or for all children within a particular household. Yet limited 
economic resources is not the only reason why a young person cannot continue their education since a household does not need to be extremely wealthy to send one of their children to secondary school. However, enthusiasm on the part of both the parents and the child is necessary, and they need to be able to perceive the relative longer-term advantages of education versus the more immediate benefits of work.

\section{Parental attitudes and family background}

Positive parental influence usually occurs where parents themselves have a relatively high level of education and more direct experience of the long-term benefits that schooling can bring. Dionicio (12), from a household of medium wealth, was not keen on continuing his education but his parents strongly encouraged him: "My dad makes me study. He wants me to do something with my life." ${ }^{6}$ His father had studied until the end of secondary school and considered education to be extremely important. His mother, with only three years of schooling, was also convinced that an education was better in the long run:

It's the only ideal inheritance that a parent can give to their child, nobody can take that inheritance away from them. Of course, it means much sacrifice but in the end, with time, it brings benefits to each person, it's useful. ${ }^{7}$ (Felicia, parent)

\footnotetext{
${ }^{5}$ Por falta de recursos economicos, no siguen estudiando. Los internados son más baratos, pero el transporte, la material, siempre es un gasto. Que tenga plata para pagar la pension, el cuarto. Los que tienen un único hijo o dos. Lo importante es tener el dinero. (Jaime, teacher)

${ }^{6}$ Mi papá me obliga a estudiar. El quiere que haga algo con mi vida. (Dionicio, 12)

${ }^{7}$ Es la única herencia más buena que un padre da al hijo, nadie le quita esa herencia. Claro, es con mucho sacrificio pero al final con el tiempo da beneficio a cada persona, da utilidad. (Felicia, parent)
} 
Thus Dionicio had been brought up listening to his parents’ admiration of education and criticism of migration, and he was expected to continue studying rather than to start paid work.

However, in contrast some parents can afford to send their children to secondary school and are willing to support them financially but the young person is not at all interested and refuses: "My parents wanted me to go, but I didn't want to"» (Nilsa, 17). In such cases, most parents are realistic: "If we send her but she doesn't study, then there's no point." ${ }^{9}$ They see little use in forcing their children to study against their will or if they have limited academic ability:

Delfín didn't want to go this year. Coming and going, he was bored with it. "I'm tired of it now" he used to say. The subjects are more difficult now in sixth grade, it's not like in first, second or third grade any more. ${ }^{10}$ (Dorotea, parent)

Thus parental attitudes can be influential in young people's choice of transition when combined with other factors rather than being a vital factor by itself.

\section{Gender}

Regarding youth transitions, there are not any notable gender differences in relation to attendance at secondary school but there are differences regarding work. Girls are more likely to carry out domestic labour whereas boys are more likely to work in

\footnotetext{
${ }^{8}$ Mis papás querían que vaya, pero yo no quería. (Nilsa, 17)

${ }^{9}$ Si nosotros mandamos y ella no estudia, de gana es. (Tomás, parent)
} 
agriculture, and this is reflected in the type of migrant work they seek. Initially, girls are more likely to migrate to the town of Tarija to work as domestic maids, rather than go to rural Argentina. Some boys also migrate to urban Tarija to work in construction or some form of manual labouring, but they are more likely to work on commercial farms in north Argentina. Some girls travel with male companions and undertake the same agricultural work. Others may accompany male relatives to cook and carry out domestic duties whilst the men work in the fields. However, girls tend to migrate to Argentina later than boys, at about 19 or 20 years old, often after an initial period of working in Tarija. Boys of 15 or 16 years tend not to pass through the intermediate stage of working in Tarija, but go further, crossing the border to Argentina.

This is largely because of parents' beliefs that girls have to be looked after whereas boys do not have to be so protected (see also Chant and Radcliffe, 1992). The proximity of Tarija means that parents can visit regularly and the young people can also return to Churquiales frequently. Young females may have to face greater negotiations with their parents when seeking migrant work. As Vicki's mother said to her when she wanted to go to Argentina: "No, we worry too much. We want you to work in Tarija where you are nearer home."11 Nevertheless, despite these increased restrictions, by engaging in step-migration young females can gradually go longer distances to a city or to Argentina which increases wages as well as parental concern:

At first I didn't like it much because I missed my family. I cried a lot and I felt very alone, but I stuck it out and stayed. I went because I had always wanted to go to

\footnotetext{
${ }^{10}$ Delfín este año no quería ir ya. Ir y volver, se aburría ya. "Ya estoy cansado" decía. Materias más costosas ya, no es como estar en primero, segundo o tercer curso. (Dorotea, parent)

${ }^{11}$ No, nos preocupa demasiado. Queremos que trabajes en Tarija donde estás más cerca de la casa. (Celia, parent)
} 
Argentina. Before that I was in Tarija, studying and working as a nanny, but there was a lot of work and they paid very little. From there I decided to go to Argentina. I told my parents and my dad let me go. ${ }^{12}$ (Mónica, 23)

Mónica went first to the town of Tarija, then to the north of Argentina and finally to the capital, Buenos Aires. She acquired her jobs through family contacts and friends, drawing on her own social networks: "I had the address and telephone number of two friends who had gone the year before. They had jobs and knew a woman who could help me get a job."13 Travelling accompanied and having a trusted friend in the place of destination, facilitated her ability to negotiate with her parents and increased the likelihood of being allowed to go. Thus, girls tend to have to use such coping strategies more frequently than boys because of increased parental restrictions on their choice of migrant destinations (see also Chant and Radcliffe, 1992).

\section{Birth order}

If it is possible for only one or two children from a family of seven or eight to continue studying, it is more likely to be the younger siblings since older siblings are able to help with the financial costs, such as by sending back remittances whilst working in Argentina or Tarija. Birth order not only affects young people’s education opportunities but can also influence migration. Whereas their older sibling may have migrated in search of work at fourteen, the youngest may be pressurised by parents

\footnotetext{
${ }^{12}$ Al principio no me gustó mucho porque extrañaba mucho a mi familia. Lloraba mucho y me sintió muy sola pero aguanté y me quedé. Me fue porque siempre había querido ir a conocer Argentina. Antes estaba en Tarija, estudiando y trabajando como niñera, pero había mucho trabajo y poco pagaban. De ahí me animé a ir a Argentina. Les dije a mis padres y mi padre me dejó ir. (Mónica, 23)

13 Tenía la dirección y número de teléfono de dos amigas que habían ido un año antes y tenían trabajos y conocían a una señora que podía ayudarme a conseguir trabajo. (Mónica, 23)
} 
and older siblings not to migrate or to delay migration until he/she is at least seventeen or eighteen years of age:

I'm the only one of my brothers that stayed in Bolivia. I went to Argentina for two seasons when I was 16. I stayed here in the community because I felt obliged to look after my parents. All of my brothers had left, and as I was the youngest my older brothers said: "Go back and look after mum and dad." I would've liked to have stayed in Argentina, and I only came back through obligation of caring for my parents. ${ }^{14}$ (Juan, parent)

If young people decide to seek migrant work, they recognise that their contribution to family labour, both domestic and agricultural, will be missed. Alfredo explained that he and his family had decided that they must wait until his younger brother had completed primary education and could replace his labour before he would be able to migrate:

I want to go to Argentina to accompany my dad, as his assistant, and to see what it's like and work. He also wants to take me, but I can't go this year because my younger brother is still in school and I have to wait until he leaves school next year, so he can help mum with the work in the field. ${ }^{15}$ (Alfredo, 12)

14 Yo soy el único de mis hermanos que se ha quedado en Bolivia. He ido a Argentina durante dos años no más cuando tenía 16 años. Me quedé porque me he sentido obligado a cuidar los mayores. Todos mis hermanos ya habían ido, y como yo soy el hijo menor mis hermanos mayores han dicho: "Andáte a cuidar los mayores." Me habría gustado quedarme allí y sólo por obligación de cuidar mis padres volví. (Juan, parent)

15 Quiero ir a Argentina a acompañar a mi papá como su ayudante, para ir a conocer y trabajar. El también quiere llevarme, pero este año no puedo porque mi hermano menor todavía está en la escuela. Tengo que esperar hasta que termine su último año, para que él pueda ayudar mi mamá en los trabajos. (Alfredo, 12) 
Hence, when most young people consider the possibility of migration, family needs are taken into account and the outcome may be as a result of a combined household decision. Thus, being a younger sibling can increase education opportunities but may constrain work options.

\section{Social networks and support}

Emigrating for either education or work purposes while young, with limited knowledge of life outside the community, can be a bewildering experience: "I always thought it was going to be great, but at first it was difficult to get used to it"16 (David, 19). Leaving home and their sheltered, relatively isolated community for the first time can be difficult and should not be underestimated as a factor inhibiting children from migrating whether to study or work. For example, Alcira's brothers asked her to go with them to Argentina as their cook, but she did not want to because: "I wasn't used to leaving my house"17 (Alcira, 16). Similarly, two families of medium wealth wanted to send one of their children to continue studying but the children refused. Both Lidia and Osvaldo were considered to be good, studious pupils by the teachers, and their parents had the financial means as well as the desire to send them: "She is very shy. We wanted to send her to Rosquetes to study but she doesn't want to leave the house"18 (Celia, parent).

However, the marked difference between migration for education or for work is that young people are much more likely to have support networks available when seeking

\footnotetext{
16 Siempre pensaba que iba a ser lindo pero al principio fue difícil acostumbrarse. (David, 19)

17 No sabía salir de mi casa. (Alcira, 16)
} 
migrant work but not for secondary education. Young people’s fear of having to go and study elsewhere alone at such a young age was also exacerbated by stories that in urban schools, children who come from the countryside are labelled 'country bumpkins' (campesinitos).

In Churquiales most households had few contacts in the town, but the majority had contacts with rural migrants in Argentina because of an established migratory network. This not only encourages new migrants to leave but also facilitates their initial move to live away from home:

As I'm going with friends and I'll know many who are there, I don't think it's going to be very difficult. Going alone would be hard and I'd miss here a lot, but with so many people I know, I don't think so. ${ }^{19}$ (Sebastián, 18)

The majority of young people travel with experienced migrants or have relatives or friends in the area of destination who can assist them in finding work and accommodation. Most expect a maximum of two weeks before they find work. In many cases, their first job is arranged before they even leave Churquiales, through a relative or friend who has already established links. The contact links between migrants is crucial in providing an extensive migrant network which facilitates the entry of newcomers (see also Roberts 1995). This makes a potentially overwhelming experience more enjoyable and less stressful. Thus available social networks enable

${ }^{18}$ Es muy vergonzosa. Queríamos ponerla en el Valle para estudiar, pero ella no quiere salir de su casa. (Beatriz, parent)

${ }^{19}$ Como estoy yendo entre amigos y boy a conocer muchos que están allá, no creo que va a ser muy difícil. Yendo solito sería duro y extrañaría harto pero con tantos conocidos, no creo. (Sebastián, 18) 
young people to cope with leaving home and starting work but do not offer the same support for those who migrate for schooling.

Role models of other rural youth

When choosing between school or work, young people have to weigh the above factors against each other until a 'decision' can be reached. Sometimes the most decisive issue may lie with their role models who may be their parents, older siblings, friends or other community members. In Churquiales, children's most influential role models are often the return migrants from Argentina: "They only think about Argentina. It's the only model they have. Their dream is to go to Argentina: to suffer, to work hard and eat little"20 (Eduardo, parent).

By the time young people in Churquiales reach their twenties, most of them will have migrated at least once to work in Tarija and/or Argentina. In contrast only one young person from the community had continued to university after completing secondary school education. The young migrants return with new clothes and consumer goods such as stereo cassette players and inspire others to leave: "I want to go too, I'm going next year”21 (Julián, 14). Exaggerated stories of how great a life the migrants lead, encourage others to join them and increase their own status within the community:

\footnotetext{
${ }^{20}$ Sólo piensan en Argentina. Es el único modelo que tienen. Su sueño es ir a Argentina: a sufrir, trabajar fuerte y comer poco. (Eduardo, parent)

21 Yo quiero ir también, voy al año. (Julián, 14)
} 
Since all the blokes of that age came to Argentina, you just wanted to go too, I was 16, just a kid. All my friends came here and then went back saying "Oh, it's just great there," so I just wanted to come here too. ${ }^{22}$ (Juvenal, parent, Fraile, Argentina)

Migrants return with their newly acquired material goods, which are their symbols of success and increased prestige. They provide children with stronger role models than the exceptional few who have achieved academic success beyond primary level. In many cases secondary education is not a viable alternative to the more immediate material gains of work and migration.

\section{Negotiated Interdependence}

In Bolivia, where a state welfare system does not exist, there are strong expectations that children should be responsible for their parents in old age, whether that be physical care or financial support (Gill 1987). In Churquiales, most young people have a strong sense of responsibility towards their family, and negotiate ways to fulfil their individual needs whilst also contributing to the household. They balance family demands and personal ambitions, and also integrate the different contexts of their lives at school, home and work. The decisions which they make in one arena, within the limited range of opportunities they have, can only be understood if one knows what is happening in the other contexts of their lives (see also Bynner, 2001; EGRIS, 2001). The constraints which face young people at home affect what they do at work or at school, and vice-versa.

\footnotetext{
22 Como todos los muchachos ya de esa edad venían, uno ya quería venirse, yo tenía 16 años, era
} chico. Todos los compañeros venían para acá y decían: "ah allá es lindo", entonces uno ya quería 
Santiago (13)'s choice of school-to-work transition is an example of how interdependence is worked out in practice. He left school and began to work as an agricultural day labourer in the community even though his parents were prepared to make the financial sacrifice to send him to secondary school: "If I wanted to study, I would have just gone"23 (Santiago, 13). However, in the end he decided:

It's not worth it, what happens if I fail? If I don't fail, I'd just have to keep on going, but I almost don't like studying now. I want to work. Studying is easier, but I want to work. ${ }^{24}$

By working as a day labourer, he provided for his own clothing and social needs. Other times, when his labour was needed, he worked on his household's land, thereby fulfiling his family responsibilities. When his parents offered him a small piece of land for his own crops, he declined because he was aware that the land was needed for family consumption rather than for the market: "In my house there's always food for me and I know that if I need something then it'll be bought for me."25

Santiago's decision not to continue his education might be considered irrational if it is only seen within the school context rather than within the interconnecting arenas of home, school and work. He was aware that continuing school would cause financial sacrifices for his family. He was also uncertain about the long-term value of schooling which was exacerbated by his lack of an educational role model to follow. His two

venirse. (Juvenal, parent)

23 Si yo quería estudiar me iba no más. (Santiago, 13)

${ }^{24}$ De gana es, por ahí me aplaza. Si no aplazo tendría que seguir no más, pero ya casi no me gusta. Quiero trabajar. Estudiar es más fácil, pero quiero trabajar. (Santiago, 13)

${ }^{25}$ En casa siempre hay para mi, y sé que si necesito algo de repente me van a comprar. (Santiago, 13) 
older brothers had migrated to work in Argentina and their material success led him to aspire to similar economic gain. His relatively sheltered social world within Churquiales meant he was not keen to migrate to study on his own and would prefer to migrate to work with his brothers. Therefore, he opted for working and acquiring greater autonomy which enabled him to contribute to his household rather than studying and remaining financially dependent on his parents. In 2000 it was heard that he was working in Argentina with one of his brothers. ${ }^{4}$ Santiago's decision shows that young people make rational choices within a range of constraints and opportunities which intersect the different arenas of their lives. Such decisions need to be understood not only within the interconnecting arenas, but also within the wider social, cultural and economic context in which they are made.

Relations of interdependence between parents and children, and between siblings continue to be negotiated after young people have left home in search of work (see also Finch and Mason 1993). Whilst parents depend on their children for care in old age, young people rely on their parents to give them access to land and animals if they decide to stay or return to the community. For example, in 1996 two brothers, Beto (26) and Ramiro (20) were both having their own houses built on a piece of their parents' land: "It's not worth them buying their own land because I'm already a bit old and my land will be for them"26 (Gabriel, parent). Both had decided to return to live in the community after having worked for several years in Argentina. When their younger brother, Osvaldo (16), had finished primary school at 12 years old, he had been persuaded by his parents and siblings not to migrate but to stay at home and continue helping his parents. Now as the two older siblings had decided to return, 
Osvaldo was planning to migrate to Argentina where he would join his sisters. Thus, the youngest sibling was about to leave and two others had decided to return.

This example shows that household relations of interdependence are renegotiated but maintained in some form over time. Thus, 'independence' is relative, and is worked out in relation to particular needs at particular times in particular contexts. Ties are maintained between children and parents, and between siblings. Individuals have different bargaining power which can be used to work out household negotiations. Bargaining power is related to what they have to offer in the negotiation, which may be their labour or material resources such as land and animals. A sense of responsibility towards each other also means that in some situations some individuals give, whilst others take, but in time each will have contributed as well as received.

However, this is not to say that household relations are always co-operative or harmonious. There are tensions which have to be balanced between satisfying individual and household needs. Some conflicts cannot be resolved to each individual's satisfaction. For example, if Beto and Ramiro had not decided to return to Churquiales, Gabriel recognised that he would probably have had to sell his land against his wishes and go to live with them in Argentina. Also individuals may change their minds and their livelihood strategies with time and in the face of new opportunities and constraints. This means that interdependent relations have to be renegotiated accordingly.

${ }^{26}$ No vale la pena que compren su propio terreno porque ya soy un poco viejo y mi terreno sería para ellos. (Gabriel, parent) 


\section{Conclusion}

This paper has shown that rural young people in Bolivia are faced with a range of multiple, and often interconnected, factors which influence their choice of school-towork transition. These include the constraints of the rural locality (particularly limited local education and work opportunities), lack of economic resources, young people's and parents’ perceived benefits of education compared with work opportunities, parental attitudes, gender, birth order, available support networks and the role models of older rural youth. What is interesting is that despite this range of structural constaints including cultural expectations of fulfilling family responsibilities, rural young people are still able to assert some level of agency over their choice of youth transition.

Migration for work rather than education is an attractive opportunity for young people as it enhances both their economic and social capital (Bourdieu, 1993), enabling them to be more flexible (see Bynner, 2001: 8). They have the choice of continuing to migrate seasonally, to return to their community or to live more permanently in Argentina or Tarija. Migration is often used by young people as a bridge between being part of their parents' household and forming a new household of their own. It allows them to accumulate savings whilst also maintaining links with their parents and siblings by sending remittances home. Each young person has to consider the benefits and drawbacks of staying or leaving according to their individual situation and personal preferences: 
At the moment I'm toying between whether to stay or go: if I go I like it, and if I stay I like it. Here I'm amongst friends and family, but in Argentina there are more economic opportunities. ${ }^{27}$ (Gónzalo, 20)

When I was in Tarija I missed the countryside, I don't like the town, it's okay for a while but then I want to come back. ... : It's more comfortable at home because you work when you want, and you can rest. ${ }^{28}$ (Sebastián, 18)

Young people in rural Bolivia negotiate ways to balance their individual needs with household responsibilities; their unpaid work at home with paid work. They weigh up the pros and cons of economic opportunities and within their constraints, they make choices.

In the minority world, where autonomy is highly valued, the ways in which young people negotiate their youth transitions have been described as 'structured individualization' (Rudd and Evans, 1998). Young people in the minority world shift between dependence and independence (EGRIS, 2001) in a more individualised way than the more interdependent relations between young people and their parents in the majority world. Rural youth transitions in Bolivia occur earlier than those of their counterparts in the minority world. Majority world young people may achieve economic independence sooner than those in the minority world, but long-term family interdependence tends to be maintained throughout the life-course. Thus, rather than conceptualising young people as moving in and out of dependence and independence,

27 Ahorita estoy balanceando: si voy allá me gusta, y si estoy aquí me gusta. Aquí estoy dentro de conocidos y estoy con la familia. Pero allá hay más oportunidades económicas. (Gónzalo, 20) 
this paper has argued that the notion of interdependence is a more appropriate way to understand relations between young people and adults in rural areas of the majority world.

As this article has shown, young people in rural Bolivia have a strong sense of responsibility and obligation to their family, yet the ways these are fulfilled in practice are negotiable. Thus, the concept of 'negotiated interdependence' is a useful term which reflects how young people in the majority world are constrained by various structures and cultural expectations of family responsibilities yet also have the ability to act within and between such constraints, balancing household and individual needs. However, some authors have argued that interdependence (Morrow, 1996; Schneider, 2000: 6), family connectedness (Brannen et al. 1994) and family responsibilities (Finch and Mason, 1993) are also important in the minority world. Therefore, the concept of 'negotiated interdependence' may also be applicable to minority world contexts where the boundaries between dependence and independence and between youth and adulthood are becoming increasingly blurred (Wyn and White, 1997). Thus, negotiated interdependence could be a useful way of understanding contemporary youth transitions and the changing relationships between adults and young people over the lifecourse in both the majority and minority world.

\footnotetext{
${ }^{28}$ Cuando estuvo en Tarija extrañaba el campo, no me gusta la ciudad, está bien para un tiempo no más, y ya quiero venir. ... Es más cómodo en casa porque así uno trabaja cuando quiere, y puede descansar. (Sebastián, 18)
} 


\section{Acknowledgements}

I am grateful to the British Academy for a Postdoctoral Fellowship which has provided me with time to write; and to the School of Geography, University of Leeds and the British Federation of Women Graduates for their financial support. I would also like to thank Ian McIntosh, Ruth Panelli and the anonymous referees whose useful comments facilitated the rewriting of this paper. 
${ }^{1}$ I prefer to use the recent terms: majority world and minority world to refer to the developing world and the developed world respectively. These terms invite us to reflect on the unequal relations between the two world areas. The minority world consists of a smaller proportion of the world's population and land mass despite using the majority of the world's resources.

${ }^{2}$ The names of the community and the respondents have all been changed in order to maintain anonymity and confidentiality.

${ }^{3}$ There are two nearby boarding schools, one is subsidised by the Church and the other by a nongovernmental organisation with European funding.

${ }^{4}$ This information was obtained via email with Joanna Campbell, a project researcher who had been working in the same region. 


\section{References}

Bourdieau, P. (1993) Sociology in question. Sage, London.

Boyden, J., Ling, B. and Myers, W. (1998) What works for working children. Rädda Barnen and UNICEF, Stockholm.

Brannen, J., Dodd, K., Oakley, A. and Storey, P. (1994) Young people, health and family life. Open University Press, Buckingham.

Bynner, J. (2001) British youth transitions in comparative perspective. Journal of Youth Studies, Vol. 4, No. 1, pp.5-23.

Caldwell, J.C., Reddy, P.H. and Caldwell, P. (1985) Educational transition in rural south India. Population and Development Review, Vol. 11, No. 1, pp. 29-51.

Chant, S. and Radcliffe, S. (1992) Migration and development: the importance of gender. In Gender and Migration in Developing Countries, pp.1-29, Chant, S. (ed). Belhaven Press, London.

Chisholm, L. and Du Bois-Reymond, M. (1993) Youth transitions, gender and social change. Sociology, Vol. 27, No. 2, pp.259-279.

Cohen, P. and Ainley, P. (2000) In the country of the blind?: youth studies and cultural studies in Britain. Journal of Youth Studies, Vol. 3, No. 1, pp.79-95. 
Du Bois-Reymond, M. (1998) 'I don’t want to commit myself yet': young people’s life concepts, Journal of Youth Studies, Vol.1, No.1, pp. 63-79.

Du Bois-Reymond, M., Diekstra, R., Hurrelmann, K. and Peters, E. (eds) (1995) Childhood and youth in Germany and The Netherland: transitions and coping strategies of adolescents. De Gruyter, Berlin.

EGRIS (European Group for Integrated Social Research) (2001) Misleading trajectories: transition dilemmas of young adults in Europe. Journal of Youth Studies, Vol. 4, No. 1, pp.101-118.

Finch, J. and Mason, J. (1993) Negotiating family responsibilities. Routledge, London.

Furlong, A. and Cartmel, F. (1997) Young people and social change. Open University Press, Buckingham.

Gill, L. (1987) Peasants, entrepreneurs and social change: frontier development in lowland Bolivia. Westview Press, Boulder.

Gillies, V. (2000) Young people and family life: analysing and comparing disciplinary discourses. Journal of Youth Studies, Vol.3, No. 2, pp.211-228.

MacDonald, R. (1998) Youth, transitions and social exclusion: some issues for youth research in the UK. Journal of Youth Studies, Vol.1, No.2, pp. 163-176. 
Morrow, V. (1996) Rethinking childhood dependency: children's contribution to the domestic economy. The Sociological Review, Vol. 44, No. 1, pp.58-77.

Morrow, V. and Richards, M. (1996) Transitions to adulthood: a family matter? Joseph Rowntree Foundation, York.

Pérez-Crespo, C. (1991) Why do people migrate? Internal migration and the pattern of capital accumulation in Bolivia. Anthropology Working Paper, No. 74, Institute for Development, Binghamton, NY.

Punch, S. (1998) Negotiating independence: children and young people growing up in rural Bolivia. University of Leeds, Ph.D Thesis.

Punch, S. (2001a) Negotiating autonomy: childhoods in rural Bolivia. In Conceptualising Child-Adult Relations, pp.23-36, Alanen, L. and Mayall, B. (eds). RoutledgeFalmer, London.

Punch, S. (2001b) Multiple methods and research relations with children in rural Bolivia. In Qualitative Methodologies for Geographers, pp.165-180, Limb, M. and Dwyer, C. (eds). Arnold, London.

Punch, S. (2001c) Household division of labour: generation, gender, age, birth order and sibling composition. Work, Employment \& Society, Vol. 15, No. 4, pp.803-823. 
Raffo, C. and Reeves, M. (2000) Youth transitions and social exclusion:

developments in social capital theory. Journal of Youth Studies, Vol. 3, No. 2, pp.147166.

Reskin, B. and Padavic, I. (1994) Women and men at work. Pine Forge Press, London.

Roberts, B. (1995) The making of citizens: cities of peasants revisited. Arnold, London.

Rudd, P. and Evans, K. (1998) Structure and agency in youth transitions: student experiences of vocational further education. Journal of Youth Studies, Vol. 1, No. 1, pp. 39-62.

Schneider, J. (2000) The increasing financial dependency of young people on their parents. Journal of Youth Studies, Vol. 3, No. 1, pp.5-20.

Wyn, J. and Dwyer, P. (1999) New directions in research on youth in transition. Journal of Youth Studies, Vol. 2, No. 1, pp. 5-21.

Wyn, J. and White, R. (1997) Rethinking Youth. Sage, London. 
Table 1: School or work activities of 13-19 year olds from Churquiales in 1996

\begin{tabular}{|c|c|c|c|c|c|c|c|c|c|}
\hline \multicolumn{5}{|c|}{ Boys } & \multicolumn{5}{|c|}{ Girls } \\
\hline \multirow[t]{2}{*}{ School } & \multicolumn{2}{|c|}{ Work at home } & \multicolumn{2}{|c|}{ Migrant work } & \multirow[t]{2}{*}{ School } & \multicolumn{2}{|c|}{ Work at home } & \multicolumn{2}{|c|}{ Migrant work } \\
\hline & $\begin{array}{c}\text { For own } \\
\text { household }\end{array}$ & $\begin{array}{c}\text { For } \\
\text { others }\end{array}$ & $\begin{array}{l}\text { Urban } \\
\text { Bolivia }\end{array}$ & $\begin{array}{c}\text { Rural } \\
\text { Argentina }\end{array}$ & & $\begin{array}{c}\text { For own } \\
\text { household }\end{array}$ & $\begin{array}{c}\text { For } \\
\text { others }\end{array}$ & $\begin{array}{c}\text { Urban } \\
\text { Bolivia }\end{array}$ & $\begin{array}{c}\text { Rural } \\
\text { Argentina }\end{array}$ \\
\hline 2 & 7 & 5 & 1 & 16 & 2 & 9 & 4 & 8 & 6 \\
\hline $3 \%$ & \multicolumn{2}{|c|}{$20 \%$} & \multicolumn{2}{|c|}{$28 \%$} & $3 \%$ & \multicolumn{2}{|c|}{$22 \%$} & \multicolumn{2}{|c|}{$24 \%$} \\
\hline
\end{tabular}

Table 2: Approximate yearly costs of secondary schooling at a subsidised boarding school

\begin{tabular}{|c|c|c|}
\hline Expense & Approx. cost per month & Approx. total cost per year \\
\hline Board and lodging & Bs.70 - $£ 10$ & Bs.700 - £100 \\
\hline Transport & Bs.7 $\quad-\quad £ 1$ & Bs.70 $-£ 10$ \\
\hline Uniform and shoes & - & Bs.140 - $£ 20$ \\
\hline Materials and courses & - & Bs.140 - $£ 20$ \\
\hline Extra spending money & Bs.20 - $\quad £ 3$ & Bs.200 - $£ 30$ \\
\hline TOTAL: & Bs.97 - $£ 14$ & Bs.1250 - £180 \\
\hline
\end{tabular}

